Revista Oficial del Poder Judicial

ÓRGANO DE INVESTIGACIÓN DE LA CORTE SUPREMA DE JUSTICIA DE LA REPÚBLICA DEL PERÚ

Vol. 10, n. ${ }^{\circ}$ 12, julio-diciembre, 2019, 219-223

ISSN versión impresa: 1997-6682

ISSN versión electrónica: 2663-9130

DOI: https://doi.org/10.35292/ropj.u10i12.33

\title{
Helder Domínguez Haro. Democracia constitucional. Elementos teóricos, desarrollo jurisprudencial e introducción bibliográfica.
}

Lima: Grijley, 2018, 220 pp.

0 (0)

La democracia, como objeto de estudio, tiene dentro del universo de la literatura jurídica un lugar privilegiado por ser una de las creaciones políticas más logradas de la cultura occidental y, por su complejidad, ha suscitado la atención de una pléyade de autores de los que se da oportuno recuento en la obra reseñada. Ello, adicionalmente, nos dice de la trascendencia que dicha institución posee como forma de organización social y como modelo de participación política.

Democracia constitucional. Elementos teóricos, desarrollo jurisprudencial e introducción bibliográfica es un libro que reúne en sus páginas las líneas estructurales que construyen el concepto de democracia, pero ligadas, íntimamente, a la aparición y evolución del llamado pensamiento constitucional, nacido a partir de la consagración de la Constitución como norma político fundacional en el Estado moderno. 


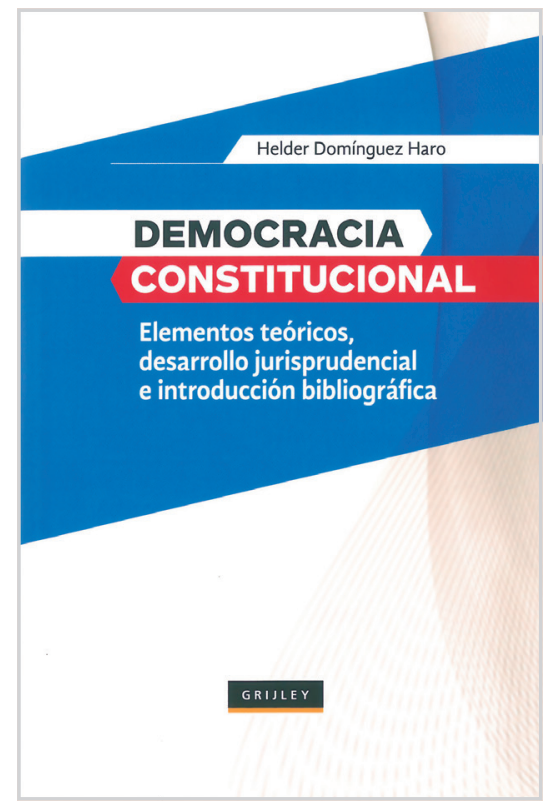

La relación conceptual surgida a partir de la simbiosis entre democracia y Constitución, o entre democracia y constitucionalismo, sitúa a la temática tratada por el autor en una posición aún más elevada. Se constituye de este modo en fuente de inspiración para nuevos estudios y variadas interpretaciones, que se acercan con acuciosidad a sus orígenes, evolución histórica, problemática actual, así como para plantear nuevos y mayores desafíos a la democracia constitucional en la sociedad contemporánea.

Presentada y prologada, respectivamente, por constitucionalistas de nota como Gerardo Ruiz-Rico Ruiz, profesor de la Universidad de Jaén, España, y José Palomino Manchego, profesor de la Universidad Nacional Mayor de San Marcos, Decana de América, la obra nos ubica - a decir del autor - «dentro del universo de ideas sobre la experiencia democrática», con el propósito de ingresar a esa cosmovisión que permita a los lectores desarrollar apego hacia lo que se ha dado en llamar «sentimiento constitucional», tan necesario para valorarla en toda su importancia, bajo la comprensión de que la democracia constitucional no es otra cosa que el cénit de la evolución democrática.

Democracia es un concepto que hemos rescatado del mundo clásico por la proximidad del modelo con la práctica social que aspiramos para nuestros días y con las nuevas formas de gobierno que surgieron tras el derrumbe de las monarquías en Occidente. La idea de un gobierno que naciera de la voluntad del pueblo, de la libre participación política e igualdad de todas las personas, ha seducido por generaciones a los pensadores sociales como la 
mejor receta para prevenir los peligros de la opresión absolutista y de la tiranía, pues si bien la democracia desarrollada en el mundo helénico escondía numerosos errores, propios de la época (como la esclavitud), la experiencia griega, sobre todo ateniense, es de innegable valor para no repetir las lecciones negativas del pasado y recorrer, por el contrario, el camino de la virtud política y cívica.

Dicho camino no es uno exento de vicisitudes y peligros; no obstante, pese al desencanto por la democracia - producto ya sea de la corrupción e ineficiencia en las instituciones públicas, el obstruccionismo parlamentario, jueces venales o la inoperancia de la clase política-, llegado un momento en el progreso social, filosófico, económico y político de la humanidad, gran parte de ella se ha decantado por la democracia como modelo social e, incluso, como experiencia vital.

Para comprender las complejidades inherentes a esta evolución, el autor perfila el fenómeno democrático presentando ideas introductorias como paso previo a reconstruir un modelo conceptual integral y sistemático de la democracia, de la mano con el paradigma constitucional-democrático de nuestro tiempo, modelo cuyo estudio implica discurrir por la gran variedad conceptual sobre lo que es la democracia, iniciando por el pensamiento de Rousseau, padre de la democracia moderna, que sintonizaba con los conceptos de democracia y soberanía popular; ideario que sería enriquecido con los desarrollos teóricos de politólogos, jusfilósofos y constitucionalistas cuyas teorías contribuyeron a la formación de una concepción moderna de la democracia y de un moderno Estado democrático.

Pero, independientemente de la gran variedad de desarrollos teóricos o de las divergencias y convergencias que puedan suscitarse, si algo merece enfatizarse con certeza es que «la democracia implica necesariamente el derecho», como refiere de modo esclarecedor 
el autor al hacerse eco del pensamiento del jurista y pensador contemporáneo Luigi Ferrajoli, quien afirma que la democracia constitucional «es un modelo de democracia producto de un cambio radical de paradigma acerca del derecho iniciado aproximadamente en el quinquenio 1945-1949, en las circunstancias culturales y políticas que vieron nacer a la Carta de las Naciones Unidas (1945)». Y no le falta razón al ilustre jurisconsulto italiano, cuyo país vio el surgimiento del fascismo, régimen totalitario que junto con el nazismo asumió un esquema político donde los derechos de las personas se subordinaban a los intereses y objetivos del Estado, es decir, donde el ciudadano estaba al servicio del Estado y no el Estado al servicio del ciudadano. Bajo ese modelo autoritario, el avasallamiento de las libertades públicas y derechos individuales, primero en Europa y luego en otros continentes, fue posible sin que el derecho pudiera ofrecer una respuesta certera que previniera a las personas de los abusos del poder.

En tal contexto, tanto la Carta de las Naciones Unidas, la Declaración Universal de Derechos Humanos de 1948, la Constitución italiana y la Ley Fundamental de la República Federal Alemana de ese mismo año, representaron la definitiva consagración de los derechos humanos y de los derechos fundamentales de la persona, es decir, aquellos derechos humanos positivados, generalmente en el texto mismo de la Constitución, con el fin de que gocen de tutela especial. El Estado constitucional vendría a ser, entonces, un sistema de garantías de los derechos fundamentales.

El cambio de paradigma fue irreversible y evidente, la persona es ahora el centro de imputación de derechos y el Estado se encuentra, definitivamente, al servicio de ella. Dicha configuración es recogida por las Constituciones de los países que se precian de poseer un sistema democrático, $y$, en nuestro caso, es la fuente de inspiración del artículo $1 .^{\circ}$ de la Constitución peruana de 1979, según el cual la persona humana es el fin supremo de la sociedad y del Estado. 
Democracia constitucional. Elementos teóricos, desarrollo jurisprudencial e introducción bibliográfica es un libro que tiene la virtud de ser, pese a la complejidad de la temática elegida, de sobria y amena lectura, de ahí que sea altamente recomendable para quien desee elucidar el fenómeno democrático desde sólidas bases teóricas y analizar, con perspectiva crítica, las referencias ilustradoras a los problemas que suele afrontar la gobernabilidad democrática.

Podemos decir - en gran parte debido al autor- que la democracia es un principio de organización estatal, un estilo vital y de proyección de la filosofía humanista, $\mathrm{y}$, - hasta el momentouna de las mejores formas de realizar la dignidad del ser humano; porque vivir y luchar por la democracia nos ayuda a comprender que, por más obstáculos que se enfrente, es una conquista de la civilización que no estamos dispuestos a perder.

Jorge Angel Chávez Descalzi Centro de Investigaciones Judiciales del Poder Judicial (Lima, Perú)

Contacto: jchavezd@pj.gob.pe https://orcid.org/0000-0003-4653-7922 